$1-17-1958$

\title{
Lord, What Wilt Thou Have Me To Do
}

Wyatt Sawyer

Follow this and additional works at: https://scholarworks.harding.edu/wyatt-sawyer-sermons

\section{Recommended Citation}

Sawyer, W. (1958). Lord, What Wilt Thou Have Me To Do. Retrieved from

https://scholarworks.harding.edu/wyatt-sawyer-sermons/357

This Sermon is brought to you for free and open access by the Wyatt Sawyer Archive at Scholar Works at Harding. It has been accepted for inclusion in Wyatt Sawyer Sermon Outlines by an authorized administrator of Scholar Works at Harding. For more information, please contact scholarworks@harding.edu.

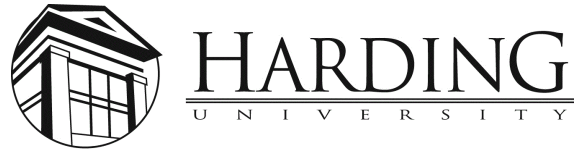


IORD, WHAT WIIT THOU HAVE ME TO DO

Acts $9: 1-8$

INT \& From beginning of human race to its end, there is one question greater than all others. Subject today.

"In the beginning GOD..", Man's knowledge starts with God; and blooms into frll fruition at judgment, God.

To get through this life successfully, and prepare for the life to come successfully, man must ask this question hundreds of thousands of times. Decisions b World divided into those who live by this question and those who don't. Iesson: Urge you to do so.

I. PAUL"WAS" BLISSFULJY"ITNORANI" AND A DOOMED MAN. Matt.7:

A. Was religious; did not make him right. Phil. 385. 21-23.

B. Being zealous did not make him right, Gal.1:14. 9:I.

C. Being sincere could not save him. Aicts $26 \% 9$. I TIm. $1: 13$

D. Men were not Christians then, and will not be so now unt1l ask: "Lord, what wilt THOU have me to do?"

II. PAUL" AWOKE" A TRFMMLING AND ASTONISHED SINNER BEFORE GOD. A. Bigger a man is, in sight of wo rld, harder it is for bine to humbio himself. I Cor. 1:26. anblenge put B. Greatest shock in Paul's life came when the Iordcalled him a murderer, instead of a saint. 9:5. C. Kust all men be stunned to reality? Peul was one. 1. IIl. Read letter. Drowming of little son.

D. How a man is awakened to his need of Christ, I care not, but he mast be in some way if he is saved.

III. PAUL'ASKKI", THEN DID WHAT THE LORD WILIED FOR HMI TO DO. A. He went to Demascus for help. We to Bible. John 8:31-32, B. He listened when he got there. We to Bible. Jas. 1:25. C. He obeyed the will of the Iord. Acts 22:16. How saved D. Paul's obedience showed three traits: Honesty, humility, and sincerety. Without which no man will see God

INV: Do you consider yourself honest? humble? sincere? Have you asked: "Lord, what wilt thou have me to do?" If not, will you not follow Paul's example? B-R-C-B. Some have newer wokel thio quection. Now.!

Christians sometimes fall from God's favor because they ceasel to ask:"Lord, what wilt thou have me to do." If you ask now, he would say: Repent and pray.

Invite any of the Iord's people who need a church home to identify with this congregation and its work. 